\title{
Rock phosphate and lime for small-scale farming in Tanzania, East Africa
}

\author{
Per Kalvig, Niels Fold, Jesper Bosse Jønsson and Elisante Elisaimon Mshiu
}

Poor soils are a major cause of poverty in sub-Saharan Africa, and thus restoration of soil fertility is a significant challenge for sustainable agriculture. Some of the main resources required, e.g. phosphate and lime, are present in many African countries and can be used by smallholder farmers in a relatively unprocessed form instead of expensive commercial fertilisers. Here we present a small study of the Mbeya region in Tanzania, which locally has both phosphate and lime.

Most soils in sub-Saharan Africa are losing nutrients necessary for sustainable agriculture. This is mainly due to intensive farming and the fact that the nutrients are not replaced adequately. Further reasons for nutrient losses are leaching, soil erosion and fixation by iron and aluminium oxides. Vast areas experience moderate to acute phosphorus deficiency (Vanlauwe \& Giller 2006).

The Mbeya region in south-western Tanzania (Fig. 1) is characterised by intensive smallholder plots along with several local sources of phosphate-bearing rocks and limestone. The former were examined in the 1980s (Chesworth et al. 1988, 1989), but have never been utilised (Kalvig et al. 2010).

\section{Phosphates and lime - opportunities and constraints}

Soils may become acid for many reasons and high rainfall may lead to washing out the nutrients needed for healthy plant growth. Thus phosphorus and calcium deficiencies are common factors that restrict plant growth in highly leached tropical soils. The majority of smallholders cannot afford to use adequate quantities of commercial fertilisers and lime, resulting in low yields. An alternative is to use local sources, which can improve agricultural productivity by slowly releasing essential elements and raising the $\mathrm{pH}$ value of the soil. Phosphates, lime, potassium-rich minerals, clay, zeolite and mica are common locally, but lacking awareness of their effects, very few smallholders use them. If such an awareness could be fostered and local resources made available at affordable prices, it would give farmers an opportunity to improve their crop yields (van Straaten 2002; Mitchell 2005). The phosphate potential in Tanzania was outlined twenty years ago by Mchihiyo (1991). The study presented here shows that local phosphate can be made available at affordable costs.

Phosphate minerals. Natural fertilisers are available and can be used untreated. They comprise organic fertilisers such as manure, leaf litter and sludge, and rock fertilisers such as marl, rock phosphate, volcanic rock and mica. In contrast to natural fertilisers, artificial fertilisers are readily soluble and contain guaranteed total, active nutrient concentrations.

The practical challenges and potential benefits involved in the use of rock phosphate have been widely discussed (Mchihiyo 1991; Appleton 2002; van Straaten 2002, 2006; Vanaluwe \& Giller 2006). The general view is that the use of rock phosphate for local agriculture is justified, provided its addition is managed in accordance with the type of crop and the conditions of the soil. Usually, crop yields only show a slow response over 2-3 years after the addition of rock phosphates, which makes it difficult to generate interest among local farmers.

The solubility of phosphate-bearing rocks differs widely depending on the mineralogy and chemistry of the rock

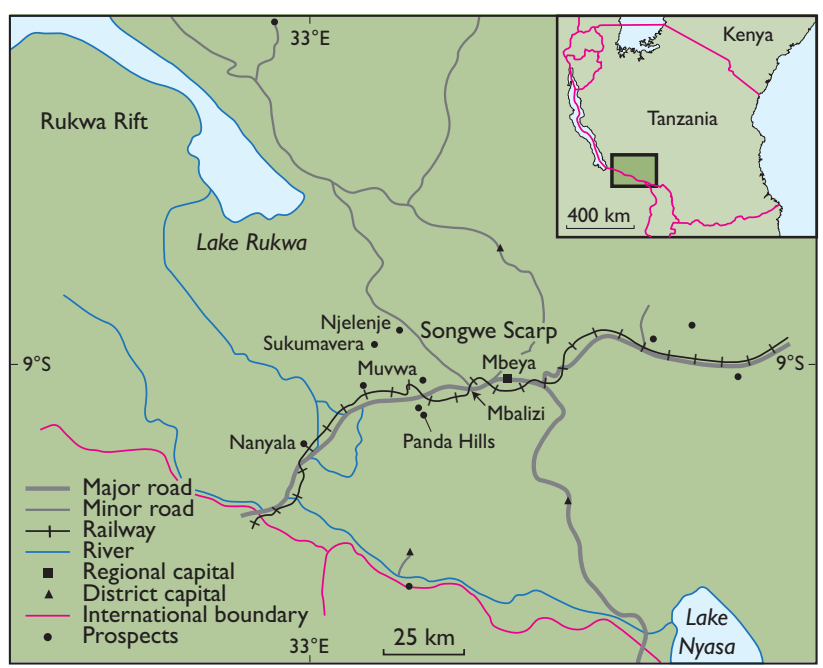

Fig. 1. Map of south-western Tanzania showing the Mbeya region with its main towns, roads and railway. The prospects indicated are known carbonatite occurrences which were considered potential phosphate resources by previous studies. 
type, and not all of them are therefore effective when applied directly to the soil. Some important factors for the successful use of rock phosphate are: (1) the type of phosphatic rock, with apatite as the most common phosphate mineral containing 34-42\% $\mathrm{P}_{2} \mathrm{O}_{5}$, (2) the reactivity of the phosphate rock, (3) the soil, where in particular $\mathrm{pH}$, cation exchange capacity, phosphorus and calcium concentration, and phosphorus-fixing capacity of the soil play important roles, (4) the type of crop, because the ability to use $\mathrm{H}_{2} \mathrm{PO}_{4}$, which dominates at low $\mathrm{pH}$, differs from crop species to crop species, and (5) fertiliser management (van Straaten 2002).

Lime. The primary reason for increasing the soil $\mathrm{pH}$ by liming is to reduce the aluminium toxicity to plants, and to ensure that $\mathrm{Ca}, \mathrm{Mg}, \mathrm{K}$ and $\mathrm{P}$ are available to the plant. Raising the $\mathrm{pH}$ value to 5.2-5.5 is adequate for increasing crop yields, whereas higher values reduce the breakdown of rock phosphate (Mitchell 2005).

\section{Phosphate and lime resources in the Mbeya region}

Geological setting. In Tanzania, a central Archaean craton is surrounded by Proterozoic fold belts (Fig. 2). The Mbeya region lies south-west of the Archaean craton in the NW-SEstriking 2000-1800 Ma old Ubendian fold belt. This fold belt is dominated by gneisses and amphibolitic rocks, intruded by $730 \mathrm{Ma}$ old syenite-gabbro complexes, all of which have been intruded by carbonatite complexes of Cretaceous to late Palaeogene age. During the late Phanerozoic, rifting and faulting occurred in connection with the formation of the East African Rift Valley. The occurrence of Neogene sediments such as conglomerate, clay and chert as well as volcanic rocks is related to the rift valley.

Phosphate in the Mbeya region. The most promising phosphate occurrence is the Songwe Scarp carbonatite, which is a $20 \mathrm{~km}$ long, $50 \mathrm{~m}$ wide, NW-SE-striking, $100 \pm 10 \mathrm{Ma}$ old ferrocarbonatite (Miller \& Brown 1963; Brown 1964). Mchihiyo et al. (1992) provide an overview of the exploration history of this carbonatite, which took place in the 1950s. The exploration focussed on uranium and comprised geological mapping of anomalous zones of the carbonatite some $2 \mathrm{~km}$ north-west of the village Njelenje (Fig. 1; Brown 1964). In the 1990s, the phosphate was assessed as a potential source of fertiliser (van Straaten 2002).

The exploration led to the recognition that several parts of the Songwe Scarp carbonatite are relatively rich in apatite. It was also discovered that areas with elevated concentrations of radioactive elements, yttrium and other rare-earth

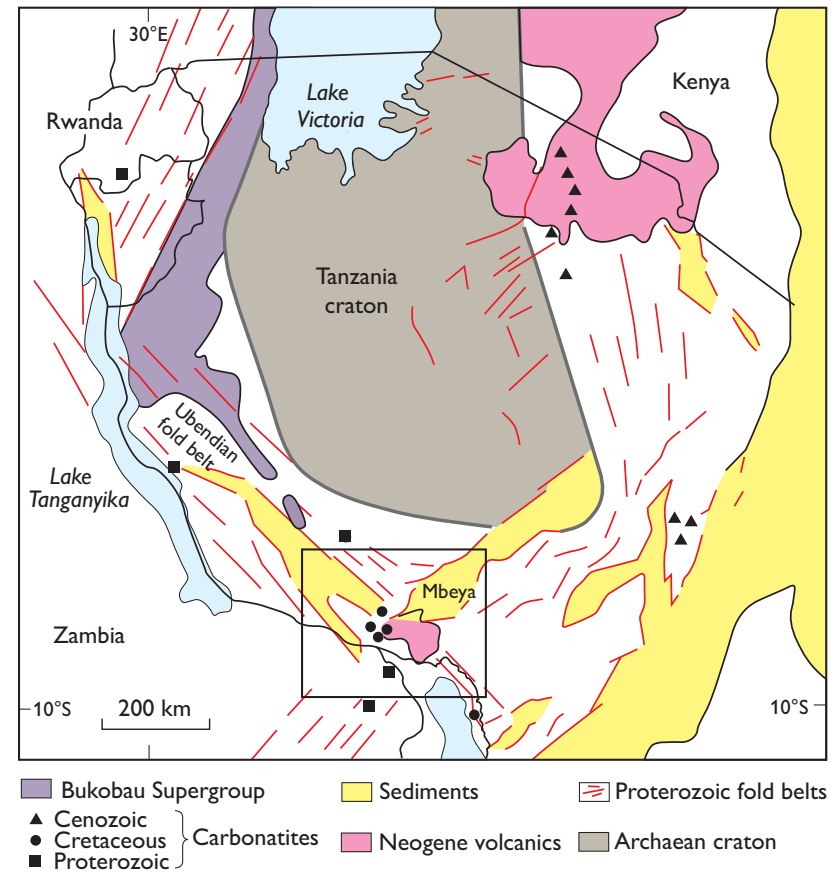

Fig. 2. Simplified geological map of Tanzania (based on van Straaten 2002). The Mbeya region (framed) is located in south-western Tanzania.

elements occur near Njelenje (Fig. 3). The highest phosphate concentrations were found in limonitic residual soils overlying the carbonatite, with up to $20 \% \mathrm{P}_{2} \mathrm{O}_{5}$ and $6 \% \mathrm{~K}_{2} \mathrm{O}$. These soils can be used as phosphate fertilisers (Chesworth et al. 1989; Appletorn 2002; van Straten 2002).

In addition to the Songwe Scarp carbonatite, the region holds several other occurrences of phosphate. One is the Panda Hills carbonatite where $c .1$ Mt of residual phosphates with a $\mathrm{P}_{2} \mathrm{O}_{5}$ concentration up to $10.3 \%$ have been mapped (van Straaten 2002). Another is the Mbalizi carbonatite where weathered parts locally form a $0.5 \mathrm{~m}$ thick limonitic crust with up to $30 \% \mathrm{P}_{2} \mathrm{O}_{5}$ (Mchihiyo 1991; Mchihiyo et al. 1992). This phosphate is under exploration as a potential source of niobium and other rare-earth elements. A third possibility of phosphate is guano from bats around Sukumavera, but the amount is far too small to play any role, even for smallholders (van Straaten 2002).

Limestone in the Mbeya region. Calcareous sedimentary rocks, mainly travertine in the Songwe valley, are mined for (1) dimension stones using a yellowish travertine near Nanyala in the Mbozi district, (2) carbonate for calcination and (3) cement production. Hochstein et al. (2000) and Roberts et al. (2004) provided geological details of this limestone unit and estimated that it covers an area of $c .13 \mathrm{~km}^{2}$ with a thickness of 5-70 m, equivalent to $>150000000 \mathrm{~m}^{3}$. An example of a weathered occurrence is shown in Fig. 4. 
Fig. 3. Landscape around the village of Njelenje in the Songwe valley, looking east and showing the Songwe Scarp carbonatite.

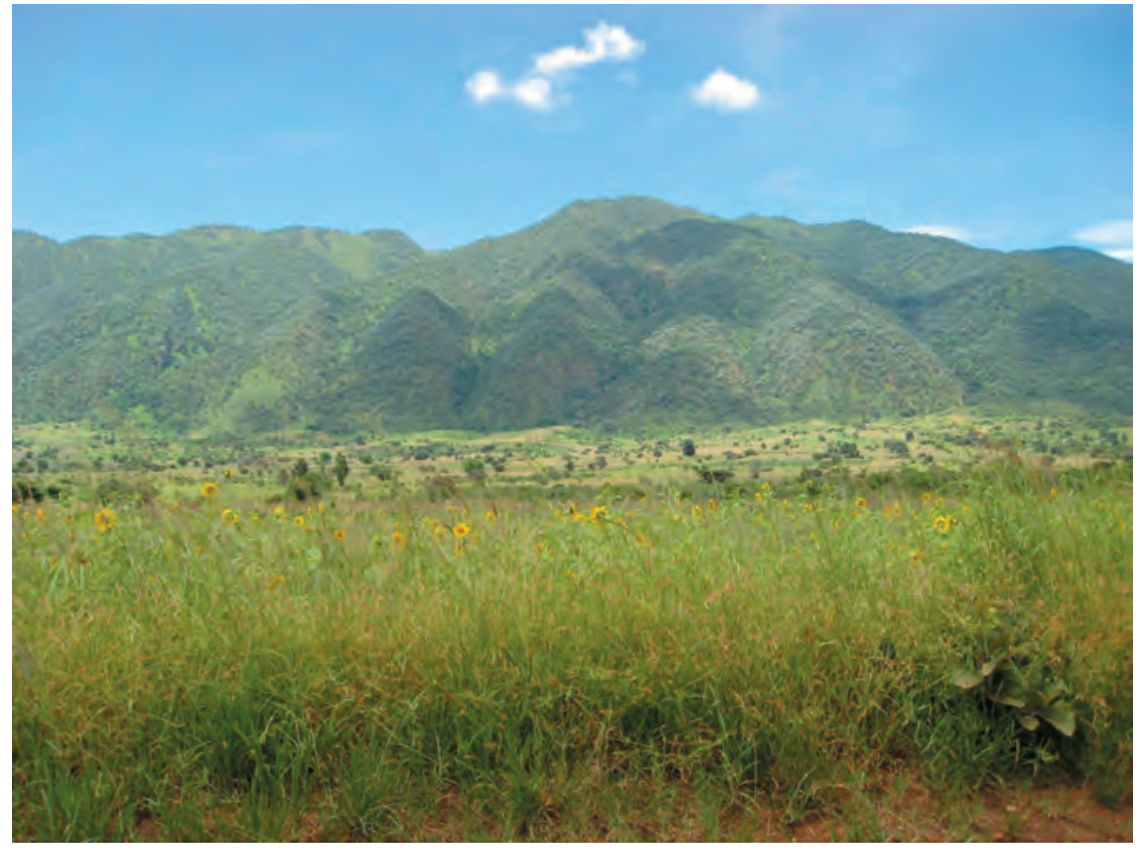

\section{Proposals for feasibility studies}

Small-scale phosphate operation to supply local smallholders. The Songwe valley area holds two potential sources for the production of local rock phosphate: carbonatite and apatite-rich residuals of carbonatite. Given that previous studies indicate that enrichment of phosphorus has taken place in the residual apatite-rich soil (Mchihiyo et al. 1992) and that a production based on such soil is technically relatively straightforward, the present study only considers this source. In the vicinity of the village of Njelenje, the $\mathrm{P}_{2} \mathrm{O}_{5}$ concentration reaches $18-20 \%$ and the $\mathrm{K}_{2} \mathrm{O}$ concentration 6\% (Mchihiyo et al. 1992).

A pilot study was conducted in March 2010. The purpose was to learn from smallholding farmers what their local cultivation practices are and get their views on requirements on and limits to the use of locally produced phosphate fertilisers. The study also aimed at clarifying the availability of local labour for small-scale phosphate extraction. The village of Muvwa, located in the Mbeya region, was chosen due to its proximity to the phosphate resources of the Songwe Scarp carbonatite (Fig. 3). The study area encompassed 420 households corresponding to 1768 inhabitants of whom 331 persons were capable of working. Twenty-one households were interviewed in order to learn about the general pattern of cultivation practices. The low number means that the results are only indicative (Kalvig et al. 2010). As no geological data on the survey area are available, the data from Njelenje, situated $c .5 \mathrm{~km}$ to the north of the interview area, may serve to indicate the total available phosphorus content of the soils in the survey area.
A feasibility study of a potential rock phosphate production is warranted and, based on a labour intensive concept producing rock fertiliser for local consumption, should (1) assess the phosphate resource (grade and tonnage estimates and the potential content of harmful elements), (2) propose a suitable set-up for the production and (3) assess the distribution and market prospects.

At this stage, no calculations of the required amount of local rock phosphate per hectare can be made, because a number of technical data are not yet available: the actual fertility of the soils of the trial area; depletion rate of phosphorus; fixation rate of phosphorus; identification of the most phos-

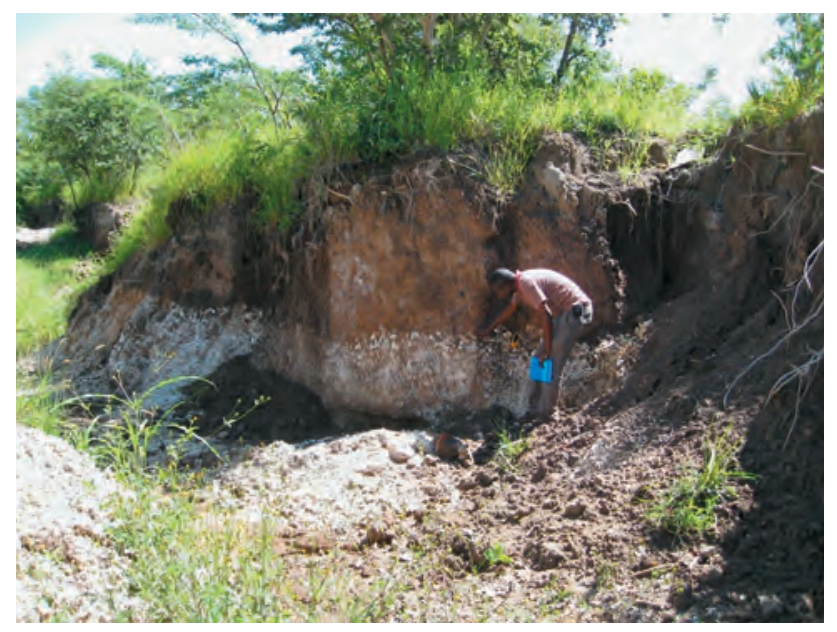

Fig. 4. Small section of limestone in the Nanyala area of the Mbeya region showing the boundary between topsoil and weathered rock. 
phorus demanding crops; the average phosphorus content of the potential rock phosphate.

Small-scale extraction of lime to supply local smallholders. In the village of Nanyala, some hundred people are involved in small-scale mining of a weathered, whitish travertine accompanied by a semi-mechanised production of hydrated lime. More than ten mining licences cover the lime producing area.

The limestone resource in the Songwe valley consists of various grades of Quaternary to Recent travertine deposits. It is dominated by poorly consolidated, partly weathered, whitish rock, of which neither the quantity nor the quality has ever been thoroughly investigated as regards lime for agricultural use. The ideal agricultural lime is a ground dolomite or dolomitic limestone with a particle size $<2 \mathrm{~mm} ; 60 \%$ $<400 \mu \mathrm{m}$ and up to $50 \%<150 \mu \mathrm{m}$ (Mitchell et al. 1997). Labour intensive production of agricultural lime is a relatively straightforward process (Mitchell \& Mwanza 2005).

The March 2010 survey included interviews with some of the operators in the neighbouring Nanyala area (Kalvig et al. 2010). Hydrolime has been produced for several years in this area. There is a potential for diversifying the existing hydrolime production to include lime products for local use and particularly for sale to local smallholders cultivating coffee. In Tanzania, agricultural lime is mainly produced in the Tanga District located $c .800 \mathrm{~km}$ from the Mbeya region.

A feasibility study on how to extend the on-going production of hydrolime to include lime for agricultural use seems warranted. It should include all steps from quarrying and marketing to testing the products and should be based on a labour intensive concept.

\section{Acknowledgements}

Geocenter Denmark is thanked for financial support, and the Tanzania Commission for Science and Technology for permission to conduct field work.

\section{References}

Appleton, J.J. 2002: Local phosphate resources for sustainable development in sub-Saharan Africa. British Geological Survey Report CR/02/121/n, $134 \mathrm{pp}$.

Brown, P.E. 1964: The Songwe scarp carbonatite and associated feldspathization in the Mbeya Range, Tanganyika. Quarterly Journal of the Geological Society 120, 223-240.

Chesworth, W., Semoka, J.M.R., van Straaten P., Mnkeni, P.M.S., Kamasho, J.A.M. \& Mchihiyo, E.P. 1988: Tanzania-Canada agrogeology project: report on completion of the first phase, $93 \mathrm{pp}$. Ontario, Canada: University of Guelph.

Chesworth, W., van Straaten, P. \& Semoka, J.M.R. 1989: Agrogeology in East Africa: the Tanzania-Canada project. Journal of African Earth Sciences 9, 357-362.

Hochstein, M.P., Temu, E.P. \& Moshy C.M.A. 2000: Geothermal resources of Tanzania. World Geothermal Congress 2000, Kyushu-Tohoku, Japan, 28 May to 10 June 2000. Proceedings 1233-1238.

Kalvig, P., Fold, N., Jønsson, J.B. \& Mshiu, E.E. 2010: Local use of agrominerals. Untapped resources for farming communities in sub-Saharan Africa. Appraisal study on the agromineral potential in the Mbeya area, Tanzania. Danmarks og Grønlands Geologiske Undersøgelse Rapport 2010/107, 58 pp.

Mchihiyo, E.P. 1991: Phosphate potential in Tanzania. Fertilizer Research 30, 177-180.

Mchihiyo, E.P., Kiranga, O.W. \& Mbasha, M.Z. 1992: Tanzania-Canada agromineral project. Report on completion of second phase (Madini Group). Unpublished report, Madini Group, Tanzania.

Miller, J.A. \& Brown, P.E. 1963: The age of some carbonatite activity in south-west Tanganyika. Geological Magazine 100, 276-279.

Mitchell, C.J. 2005: Farm lime: low cost lime for small-scale farming. British Geological Survey Technical Report CR/03/066N, 138 pp.

Mitchell, C.J. \& Mwanza, M. 2005: Manual for small-scale production of agricultural lime. British Geological Survey Commissioned Report CR/05/092N, $31 \mathrm{pp}$.

Mitchell, C.J., Inglethorpe, S.D.J., Tawodzera, P., Bradwell, S. \& Evans, E.J.M. 1997: Local development of affordable lime in southern Africa. British Geological Survey Technical Report WC/94/20, 120 pp.

Roberts, E.M., O'Connor, P.M., Gottfried, M.D., Stevens, N., Kapalima, S. \& Ngasal, S. 2004: Revised stratigraphy and age of the Red Sandstone Group in the Rukwa Basin, Tanzania. Cretaceous Research 25, 749-759.

van Straaten, P. 2002: Rocks for crops. Agrominerals of sub-Saharan Africa, 338 pp. Nairobi, Kenya: International Centre for Research in Agroforestry.

van Straaten, P. 2006: Farming with rocks and minerals: challenges and opportunities. Anais da Academia Brasileira de Ciências 78, 731-747.

Vanaluwe, B. \& Giller, K.E. 2006: Popular myths around soil fertility management in sub-Saharan Africa. Agriculture, Ecosystems and Environment 116, 34-46.

\footnotetext{
Authors' addresses

P.K., Geological Survey of Denmark and Greenland, Øster Voldgade 10, DK-1350 Copenhagen K, Denmark. E-mail:pka@geus.dk

N.F., Department of Geography and Geology, University of Copenhagen, Øster Voldgade 10, DK-1350 Copenhagen K, Denmark.

J.B.J., School of Geographical \& Earth Sciences, University of Glasgow, Glasgow G12 8QQ, Scotland, UK.

E.E.M., Department of Geology, University of Dar es Salaam, P.O. Box 35052, Dar es Salaam, Tanzania.
} 